\title{
Validating a Conceptual Framework for Benchmarking Implementation in SMEs at Six Case Study Companies
}

\author{
Baba Md Deros ${ }^{1}$, Sha'ri Mohd Yusof ${ }^{2}$ and Azhari Md Salleh ${ }^{3}$ \\ ${ }^{1}$ Faculty of Engineering \& Built Environment, \\ Universiti Kebangsaan Malaysia, \\ 43600 UKM Bangi, Selangor, \\ Malaysia \\ ${ }^{2}$ Faculty of Mech. Engineering, \\ Universiti Teknologi Malaysia \\ 81310 UTM Skudai, Johor, \\ Malaysia \\ ${ }^{3}$ Akademi Tentera Malaysia (ATMA) \\ Universiti Teknologi Malaysia \\ 81310 UTM Skudai, Johor, \\ Malaysia \\ E-mail:hjbaba@vlsi.eng.ukm.my
}

Received Date: $28^{\text {th }}$ August 2006 Accepted Date: $7^{\text {th }}$ March 2007

\begin{abstract}
This paper presents the case study results of a conceptual framework for benchmarking implementation in Small and Medium Enterprises (SMEs), which had taken into consideration of SMEs strengths, weaknesses and characteristics. This framework provides a guide on the approach"how to"implement benchmarking, which is simple in structure, systematic and easily understood. The conceptual framework described in this paper was based on gradual implementation and selection of the appropriate key performance measures and benchmarking techniques as and when necessary, with the ultimate aim of improving business competitiveness and performance. Finally, the paper culminates with discussions, suggestions and comments by six case study companies with respect to the conceptual framework applicability and usability in the SMEs environment.
\end{abstract}

Keywords: Benchmarking, competitiveness, framework, SMEs, complex.

\section{ABSTRAK}

Kertas kerja ini membentangkan keputusan kajian kes ke atas sebuah kerangka konsep untuk pelaksanaan tanda aras di pengusaha kecil dan sederhana (PKS). Kerangka konsep ini telah dibangunkan dengan mengambil kira kekuatan, kelemahan dan ciri PKS. Struktur kerangka yang ringkas boleh menyediakan garis panduan sistematik dan mudah difahami mengenai pendekatan "bagaimana" untuk melaksanakan tanda aras. Kerangka konsep yang diperihalkan dalam kertas kerja ini telah dibangunkan berdasarkan 
kepada pelaksanaan tanda aras secara berperingkat dan pemilihan ukuran prestasi dan teknik yang bersesuaian mengikut keperluan. Matlamat utamanya ialah untuk mempertingkatkan lagi daya saing dan prestasi perniagaan. Kertas kerja ini diakhiri dengan perbincangan, cadangan dan komen yang telah diberikan oleh enam buah PKS kajian kes terhadap kebolehaplikasian dan kegunaan kerangka konsep ini di persekitaran PKS.

Kata kunci:Tanda aras, daya saing, kerangka, PKS, kompleks.

\section{INTRODUCTION}

Since, in the early 1980s benchmarking has been gaining attention and acceptance worldwide as an instrument of continuous improvement in the context of total quality management (TQM) among academicians and business managers as a means of enhancing their ability to compete in the market place (Carpinetti \& De Melo 2002). In other words, business survival and success in a competitive market place can be realized by implementing benchmarking to improve key business processes, customer satisfaction and business competitiveness. In addition, benchmarking can be utilized for investigating the strengths and weaknesses in current business process. The literature shows that current benchmarking frameworks seem to have been developed primarily from the context and experiences of large organizations and tend to be complex and too prescriptive. Small and Medium Enterprises (SMEs) differ from large organizations in terms of structure, systems and processes, level of technical and management knowledge and resources constraints. In addition, benchmarking involves a lot of complex processes and activities, without an appropriate and systematic framework, it might be difficult to achieve the desired outcomes.

Aalbregtse et al. (1991) provide an excellent description of what a framework should consist of and its objectives. Meanwhile, Dale (1994) suggests that a framework can act as a roadmap in developing and presenting ideas, concepts and plans that could guide one's action. In other words, there is a clear relationship between benchmarking and improvement strategies in the sense that if it is to be used as part of the business strategy for gaining and maintaining competitive advantage, improvement projects must be prioritized by taking into consideration the company performance levels relative to its competitors as regards to their products and operational aspects (Carpinetti \& De Melo 2002).
On the other hand, the authors believe a framework could be used to present a picture or roadmap of what is required in implementing the benchmarking effort. Therefore, the authors held the opinion that a systematic framework needs to be developed first before embarking on benchmarking implementation to assists and ensures its successful implementation and adoption in any organisation. Having done that, companies could then use the framework to choose an appropriate starting point and course of action in implementing benchmarking at a pace that suits their business environment and available resources.

\section{DEFINITIONS FOR FRAMEWORK}

At present, there is no consensus on the definition of the frameworks; some writers define it as a set of principles or ideas used as a basis for one's judgement, decisions, while others portray the frameworks through diagrams, flowcharts, and graphical or pictorial representations (Yusof 2000).The Oxford's Advanced Learner Dictionary of current English defines a framework as "a structure giving shape and support" (Hornby 1990). Struebing and Klaus (1997) believed a sound framework should define what the organisation does, what it is trying to do, how it is going to do it and ensure that each step is done in the correct sequences. Meanwhile, Popper (1994) defines a framework as a set of basic fundamental principles, which can help to promote discussions and actions. In other words, a sound framework can link-up between benchmarking concept and practical application because it guides the organisation in adopting and implementing benchmarking activities or processes in a more systematic, comprehensive, controlled and timely manner.

\section{WHY NEED A FRAMEWORK?}

The most frequent reason cited for causing change efforts (such as benchmarking, TQM, 
$B P R$, reengineering, etc.) failure may be due to wrong implementation approaches. Aalbregtse et al. (1991) cited the following four reasons why a framework is needed:

a. To illustrate an overview and communicate a new vision to the organisation;

b. To force management to address a substantial list of key issues which otherwise might not be addressed;

c. To give valuable insights into the organisation's strengths and weaknesses, and its overall strategic position in the market-place;

d. To support implementation and to improve the chance of success because it will provide not only overview but also more detailed information describing the content of each framework element and its relationship to other elements. performance and competitiveness. Without a suitable benchmarking framework that provide the overall roadmap, describes the steps and guides what actions to be taken, which is easy to use, a company will face many difficulties and problems in conducting the benchmarking effort.

\section{CHARACTERISTICS OF LARGE ORGANISATIONS VERSUS SMES}

There are many significant structural differences between large organizations and SMEs. The differences are likely to influence the relevance, planning and implementation of the benchmarking concepts. Welsh \& White (1981) suggested that "a small business is not a little large business" since there are many differences between large businesses and SMEs such as in

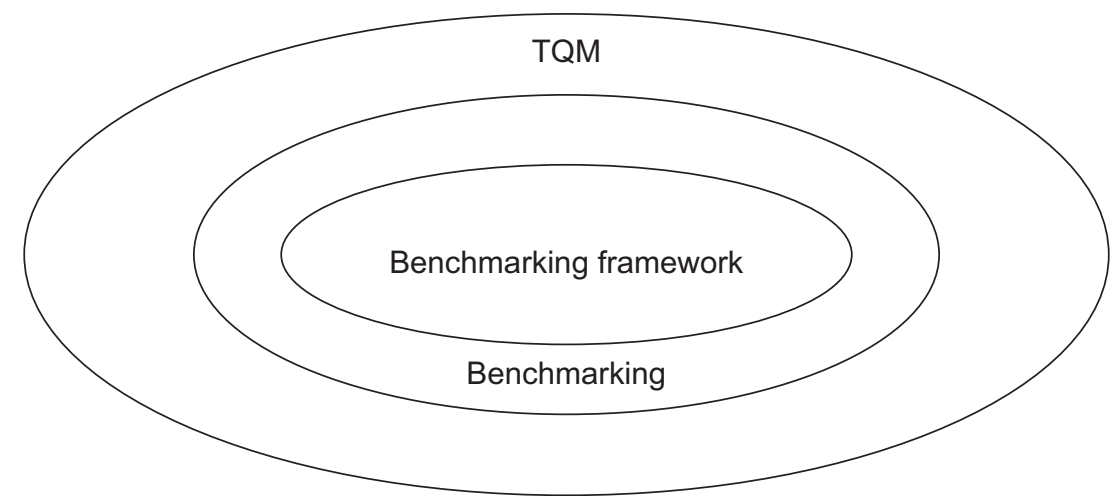

FIGURE 1. Benchmarking framework's relationship with benchmarking and TQM

Aalbregtse et al. (1991) had cited the above reasons with respect to a TQM implementation. In the authors' opinion, these reasons are also applicable to the benchmarking implementation, since benchmarking is one of the tools found in TQM.The relationship of benchmarking framework with benchmarking and TQM can be summarised and represented pictorially in Figure 1 . As can be seen, the benchmarking framework is at the heart of the benchmarking process and thus plays a very important role in ensuring the success of benchmarking process, which in turn, leads to success of the overall TQM program. Generally, companies need to know their strengths and weaknesses first before embarking on adopting the TQM philosophy to improve their customer satisfaction, productivity, product quality, process efficiency and services, which in turn lead to improvement in their overall business terms of structure, policy making procedures and utilization of resources to the extent that the application of large business concepts directly to SMEs may not be appropriate. For example, majority of SMEs are faced with frequent shortages, fluctuation in raw material price, unable to obtain credit terms, inadequate inventory management and control of stock in raw materials and less bargaining power compared to large companies (Kraipornsak 2002; Chee 1987). In general, large organisations and SMEs have five main characteristics, namely: structure, systems and procedures, culture and behaviour, human resources, and also market and customers. Table 1 gives a summary of the large organisations and SMEs characteristics. Meanwhile, Table 2 provides the SMEs strengths and weaknesses in competing against large organisations. 
Referring to Table 1 and Table 2, SMEs are in a more advantageous position in terms of structure because it facilitates faster communication line, quick decision-making process and implementation, short decision-making chain, higher contribution as a source of ideas in their operations and innovation, unified culture and very few interest groups (Kraipornsak 2002). Majority of SMEs have simple systems and procedures, which allows flexibility, immediate feedback, better understanding and quicker response to customer needs or demands than larger firms (Kraipornsak 2002). This is further enhanced by the SMEs corporate mind-set (i.e. top management act as the key driver in organizational and cultural change activities), which is conducive for new change initiatives, provided that the owner or management has the commitment to, and leadership of the change process, together with a sound knowledge of it. In addition, SMEs employees are given high authority, commitment and responsibility in their own work areas that can create cohesion and enhance common purposes amongst the workforce to ensure that a job is done well.

Innovative environment, employees and

TABLE 1. Characteristics of SMEs versus large organizations

\begin{tabular}{|c|c|c|}
\hline $\begin{array}{l}\text { Organizational } \\
\text { Characteristics }\end{array}$ & SMEst & Large Organizations \\
\hline STRUCTURE & $\begin{array}{l}\text { - Flat with very few layers of } \\
\text { management, top management } \\
\text { highly visible and close to the } \\
\text { point of delivery. } \\
\text { - Less delegation. } \\
\text { - Division of activities limited and } \\
\text { unclear. } \\
\text { - Low degree of specialisation. } \\
\text { - Flexible structure and } \\
\text { information flows. } \\
\text { - Strategic process incremental } \\
\text { and heuristic. }\end{array}$ & $\begin{array}{l}\text { - Many layers of management } \\
\text { levels, top management not } \\
\text { visible and far from the point of } \\
\text { delivery. } \\
\text { - A lot of delegation. } \\
\text { - Clear division of activities. } \\
\text { - High degree of specialisation. } \\
\text { - Rigid structure and information } \\
\text { flows. } \\
\text { - Strategic process done } \\
\text { wholesale. }\end{array}$ \\
\hline & $\begin{array}{l}\text { - Activities and operations not } \\
\text { governed by formal rules and } \\
\text { procedures. } \\
\text { - Low degree of standardisation } \\
\text { and formalisation. } \\
\text { - People-dominated. }\end{array}$ & $\begin{array}{l}\text { - Activities and operations } \\
\text { governed by formal rules and } \\
\text { procedures. } \\
\text { - High degree of standardisation } \\
\text { and formalisation. } \\
\text { - System-dominated. }\end{array}$ \\
\hline $\begin{array}{l}\text { SYSTEMS \& } \\
\text { PROCEDURES }\end{array}$ & $\begin{array}{l}\text { - Simple planning and control } \\
\text { system. } \\
\text { - Incidences of "gut feeling" } \\
\text { decisions are more prevalent. } \\
\text { - Informal evaluation, control, and } \\
\text { reporting procedure. } \\
\text { - Flexible and adaptable } \\
\text { processes. }\end{array}$ & $\begin{array}{l}\text { - Complicated planning and } \\
\text { control system. } \\
\text { - Most decisions made based on } \\
\text { facts. } \\
\text { - Formal evaluation, control, and } \\
\text { reporting procedure. } \\
\text { - Rigid and non-adaptable } \\
\text { processes. }\end{array}$ \\
\hline & $\begin{array}{l}\text { - Operations and behaviour of } \\
\text { employees influence by owners'/ } \\
\text { managers' ethos and outlook. }\end{array}$ & $\begin{array}{l}\text { Operations and behaviour of } \\
\text { employees not-influence by } \\
\text { managers' ethos and outlook. }\end{array}$ \\
\hline $\begin{array}{l}\text { CULTURE \& } \\
\text { BEHAVIOUR }\end{array}$ & $\begin{array}{l}\text { - Organic, not strong } \\
\text { departmental/functional mind- } \\
\text { set, corporate mind-set. } \\
\text { - Unified/Fluid culture. } \\
\text { - Result-oriented. }\end{array}$ & $\begin{array}{l}\text { - Rigid and strong departmental/ } \\
\text { functional and corporate mind- } \\
\text { set. } \\
\text { - Non-unified culture. } \\
\text { - System-oriented. }\end{array}$ \\
\hline
\end{tabular}


HUMAN

RESOURCES

MARKET \& CUSTOMERS
- High personal authority and commitment of the owner.

- Few decision makers.

- Dominated by pioneers and entrepreneurs.

- Individual creativity encourages and high incidence of innovativeness.

- Modest human capital, financial resources and know-how.

- Individuals normally can see the results of their endeavours.

- Low incidence of unionisation.

- Low degree of resistance to change.

- More generalists, some staff may cover more than one department.

- Span of activities narrow.

- Limited external contacts.

- Normally dependent on small customer based close contact, easily accessible and many known customers personally.

- Product and services mostly for local market, few national or international.
- Many decision makers.

- Encourages group/team creativity.

- Abudant skilled human capital, financial resources and knowhow.

- Individuals could not see directly the results of their endeavours.

- High incidence of unionisation.

- High degree of resistance to change.

- More specialists, dedicated only to one department.
- Large span of activities.

- Large external contacts.

- Normally dependent on large customer, compete based on quality, price and delivery performance.

- Products and services for local and international market.

(Source: Chee 1987; Salleh \& Fichtner 1991; Huxtable 1995; Ghobadian \& Gallear 1996; 1997; Yusof \& Aspinwall 2000a; 2000b; Hashim \& Wafa 2002; Kraipornsak 2002).

TABLE 2. SMEs' strengths and weaknesses

\begin{tabular}{|c|c|c|}
\hline $\begin{array}{c}\text { SMEs } \\
\text { Characteristics }\end{array}$ & Strengths & Weaknesses \\
\hline STRUCTURE & $\begin{array}{l}\text { - Faster communication line, quick } \\
\text { decision-making process, faster } \\
\text { implementation. } \\
\text { - Short decision-making chain. } \\
\text { - High incidence of innovativeness } \\
\text { and unified culture. } \\
\text { - Very few interest groups. } \\
\text { - Breeding ground for new } \\
\text { business ventures and } \\
\text { entrepreneurs. }\end{array}$ & $\begin{array}{l}\text { - Low specialisation may result } \\
\text { in lack of expertise in change } \\
\text { initiatives. } \\
\text { - Need outside assistance. } \\
\text { - Owner controls everything } \\
\text { and lacks delegation can stifle } \\
\text { growth. } \\
\text { - Lack of capital and credit } \\
\text { facilities. }\end{array}$ \\
\hline $\begin{array}{l}\text { SYSTEMS \& } \\
\text { PROCEDURES }\end{array}$ & $\begin{array}{l}\text { - Simple system encourage } \\
\text { innovation, allows flexibility and } \\
\text { speed of response to customer } \\
\text { needs/demands. } \\
\text { - Act as training ground for new } \\
\text { entrepreneurs and workers. }\end{array}$ & $\begin{array}{l}\text { - Lack of proper system - difficulty } \\
\text { in ensuring efficiency of work, } \\
\text { and high variability in work } \\
\text { outcome. } \\
\text { - Lack of proper/effective time and } \\
\text { cash flow management. }\end{array}$ \\
\hline
\end{tabular}




\begin{tabular}{|c|c|c|}
\hline $\begin{array}{l}\text { CULTURE \& } \\
\text { BEHAVIOUR }\end{array}$ & $\begin{array}{l}\text { to company. } \\
\text { - As a seed-bed from which large } \\
\text { companies grow. } \\
\text { - As a group provides significant } \\
\text { economic output and savings in } \\
\text { foreign exchange. }\end{array}$ & $\begin{array}{l}\text { owner/manager ethos can } \\
\text { damage new initiatives. } \\
\text { Danger when loyalties and } \\
\text { emotional ties are place above } \\
\text { competence and performance. }\end{array}$ \\
\hline $\begin{array}{l}\text { HUMAN } \\
\text { RESOURCES }\end{array}$ & $\begin{array}{l}\text { - High authority, commitment } \\
\text { and responsibility can creates } \\
\text { cohesion and enhance common } \\
\text { purposes amongst the workforce } \\
\text { to ensure job is done. } \\
\text { - Innovative environment will } \\
\text { support improvement culture. } \\
\text { - Early union involvement needed } \\
\text { to ensure success. } \\
\text { - Fewer employees - better } \\
\text { relationship, knows almost } \\
\text { everyone. } \\
\text { - Provides employment } \\
\text { opportunities. }\end{array}$ & $\begin{array}{l}\text { - Lack of financial support e.g. } \\
\text { no training budget, ad-hoc, and } \\
\text { small-scale approach can stifle } \\
\text { improvement efforts. } \\
\text { - Improvement needs investment } \\
\text { in human resources. } \\
\text { - Shortage of skilled workers. }\end{array}$ \\
\hline $\begin{array}{l}\text { MARKET \& } \\
\text { CUSTOMERS }\end{array}$ & $\begin{array}{l}\text { - Immediate feedback from } \\
\text { customers. } \\
\text { - Able to respond quicker. } \\
\text { - Understand better customer } \\
\text { needs. } \\
\text { - Aid to large companies. } \\
\text { - Stimulate market competition. }\end{array}$ & $\begin{array}{l}\text { - Marketing constraints and } \\
\text { knowledge. } \\
\text { - International marketing } \\
\text { expensive, after sales support } \\
\text { not as extensive as large } \\
\text { businesses. } \\
\text { - Easily suppressed and dictated } \\
\text { by larger multinationals (if they } \\
\text { are customers) e.g. product cost, } \\
\text { etc. }\end{array}$ \\
\hline
\end{tabular}

- Corporate mind-set is conducive for new change initiatives.

- High staff loyalty and hard work to company.

As a seed-bed from which large companies grow.

As a group provides significant economic output and savings in

High authority, commitment and responsibility can creates cohesion and enhance common purposes amongst the workforce to ensure job is done.

Innovative environment will

\section{RESOURCES}

(Source: Chee 1987; Salleh \& Fichtner1991; Huxtable 1995; Ghobadian \& Gallear 1996; 1997; Yusof \& Aspinwall 2000a; 2000b; Hashim \& Wafa 2002; Kraipornsak 2002).

union involvement will achieve higher job satisfaction among its workers, who support the improvement culture and ensure its success compared to large business organizations. SMEs have fewer employees and everybody seems to know almost everyone, thus promoting a better relationship between employees.

On the other hand, SMEs have a number
- "Gut feeling" approach may result in wrong decisions.

- Limited application of new technology.

- Inadequate infrastructure.

- Shortage of raw materials.

- Lack of managerial and technical expertise.

- Uncommitted or dictatorial owner/manager ethos can emotional ties are place above competence and performance.

Lack of financial support e.g. no training budget, ad-hoc, and small-scale approach can stifle Improvement needs investment in human resources.

Marketing constraints and knowledge.

International marketing expensive, after sales support not as extensive as large

Easily suppressed and dictated by larger multinationals (if they etc. of major weaknesses, which can result in disadvantageous situation such as majority of SMEs do not have adequate financial resources and lack of access to commercial lending (i.e. difficult to obtain loans) (Hashim \& Wafa 2002; Kraipornsak 2002). As a result, SMEs do not have adequate budget for staff training, training carried out on ad-hoc basis and small-scale 
approach, which can stifle improvement efforts.

In terms of human resources, SMEs are always faced with the shortage of skilled labour and they have to compete with large companies for skilled workers (i.e.large companies able to offer skilled workers better wages and working conditions) (Reed et al. 2001; Chee 1987). Majority of SMEs entrepreneurs have low level of formal education and limited training in new management principles and practices, which led to lack of managerial and technical expertise (Hashim \& Wafa 2002; Chee 1987).Very often SMEs relied on one-person management, thus insufficient time and attention is given to the various managerial functions (Hashim \& Wafa 2002). In SMEs, the owner controls everything; poor management was attributed to the owners' lack of experience in the business, lack of management training/ experience or know-how (Pickle \& Abrahamson 1990; Baumack 1988).

Furthermore, most SMEs lack of effective time and cash flow management system that can cause high variability in work outcome and difficulty in ensuring efficiency of work. In addition, many important business decisions are made based on "gut-feeling" and not on facts, which may result in making wrong decisions. SMEs also faced other problems such as lack of knowledge in marketing techniques, lack of opportunities at both local and international levels, poor accessibility to the distribution channels and market information, marketing constraints such as pricing, late payment from customers, inability to provide quality product and lack of promotional strategies (Kraipornsak 2002). Very few SMEs owners have prepared adequate feasibility study of their new enterprise and a sound marketing investigation (Meredith \& Grant 1982). In most cases, marketing investigation by potential entrepreneurs tend to be low level and based on general opinions rather than expert advice, lack of effective selling techniques and market research (Hashim \& Wafa 2002).

As indicated by Kraipornsak (2002) and Chee (1987), majority of SMEs rely on outdated technology, labour intensive and traditional management practices. Meanwhile, some do not trust new technology, while others are unable to afford it, which in many cases led to inefficient, lack of information and inadequate in-house expertise (Hashim \& Wafa 2002). Thus, it is important to appreciate the differences that exist between SMEs and large business organizations.
In other words, it is crucial to try and understand SMEs issues and characteristics before making any attempt to help them in implementing TQM activities (such as 7 QC tools, SPC, quality assurance system and benchmarking). Thus, it can be concluded that appropriate technology and efficient production plays important role in determining the SMEs comparative advantages and competitiveness against large companies (Kraipornsak 2002).

\section{FRAMEWORK DESIGN REQUIREMENTS}

The small and medium sized enterprises characteristics; strengths and weaknesses versus large organization had been discussed earlier. A question, which arises then, is how one can characterise a good framework that really suits the SMEs. In general, the following criteria can be considered as a guide in developing a good framework to suit the SMEs characteristics (Yusof \& Aspinwall 2000a): systematic and easily understood; simple in structure; having clear links between the elements or steps outlined; general enough to suit different contexts; represent a road map and a planning tools for implementation;answers"how to?"and not"what is?" and; implementable at reasonable cost and time. Thus, it is important that these criteria are considered when developing a framework for SMEs.

Medori \& Steeple (2000) summarised the design requirements for developing a framework that include procedures for selecting measures, procedures for implementing measures, ability to identify whether existing measurement system is up to date and measuring critical issues (i.e. audit capability). In addition, they suggested the selected measures should be congruent with company strategy and have strong relationship with the six core competitive priorities (i.e.quality, cost, flexibility, time, delivery and future growth), facilitates rapid selection of measures from a data bank and handbook approach (i.e. step-by-step methodology).

\section{DEVELOPMENT OF THE CONCEPTUAL FRAMEWORK FOR IMPLEMENTATING BENCHMARKING IN SMES}

The criteria to support the framework have been explained earlier, however, the arguments of 'large company framework's criteria has not been stresses and emphasized, in order to support or 
differentiate this framework. In this paper, the authors proposed a conceptual framework, which represent the authors' initial idea and based on the shortcomings of previous frameworks studies found in the literature. It will be used to guide and aid in the process of developing an implementation framework believed to be suitable for benchmarking implementation in SMEs. The criteria that one needs to consider when developing a framework that suit the SMEs characteristics had been explained in the previous section.

\section{ELEMENTS IN THE FRAMEWORK}

The conceptual framework was developed based on ideas and concepts established from the literature review. In the case of embarking on a benchmarking initiative, one can begin by analysing one's own performance in areas such as process efficiency, product cost, product's quality and customer satisfaction. The benchmarking implementation and adoption process will be divided into several key areas to facilitate a systematic explanation. First of all, the company must prepare an implementation strategy that describes in details the steps to be taken while planning and preparing for the benchmarking project. The content of this implementation strategy may include the following items:

1. Creating a policy making committee at company level for managing and coordinating benchmarking activities;

2. Creating vision, mission and policy statements focusing on business competitiveness through benchmarking;

3. Planning education and training for top management and members of policy making committee on benchmarking concepts, tools and techniques;

4. Select and trial run the first key business performance measure/indicator to be benchmarked;

5. Appraising the company's current level in key business performance indicators/measures.

As shown in the conceptual framework (i.e. Figure 2), the company must have a top management or policy-making committee (i.e. at company level). Its major roles are to create business vision and mission, provides commitment, leadership, coordination and resources, to make policy decisions, critical success factors, to decide on key business performance measures/indicators towards implementing benchmarking initiatives/efforts in the company and to review all activities in the benchmarking process. Members of this committee should comprise of representatives from the managerial, supervisory and operator level, and the most important of all in order to ensure success, they must be empowered with the appropriate authority and responsibility.

Understanding of the benchmarking concept, tools and techniques are essential not only to employees, who will be directly involved in the benchmarking activities such as data gathering, but also by top management, who will use the benchmarking result in decision making. The organisation needs to have a systematic data collection system and to conduct a pilot run prior to embarking on full scale benchmarking initiatives. The selection of the benchmarking techniques will be totally dependent upon the needs of a company. However, for a company, which has no prior benchmarking implementation experience, it is recommended to start by conducting the selfassessment exercise in key business areas and performance measures/indicators, followed by internal benchmarking, and then progress to external benchmarking and finally best practices benchmarking.

The results from the self-assessment exercise act as a benchmark, which in future can be use as a reference. This is to allow systematic and gradual learning of the benchmarking concepts and avoid implementation failure in the first attempt. For example, internal benchmarking is less challenging compared to external benchmarking because in internal benchmarking one is comparing between functional areas/ departments within one's own company. In this context, the system, organizational culture, working environment, communications, etc. are similar and it is easy to get comparative data because there is no conflict of interest. Meanwhile, the critical success factors (CSFs) as depicted in Figure 2 act as enablers to drive and create an environment and culture, which is conducive for benchmarking implementation and adoption process. In other words, without the CSFs in place, the benchmarking initiatives shall have to face with a lot of implementation hurdles and barriers, which in the end may endup in failure.

According to the SMEs characteristics (i.e. 


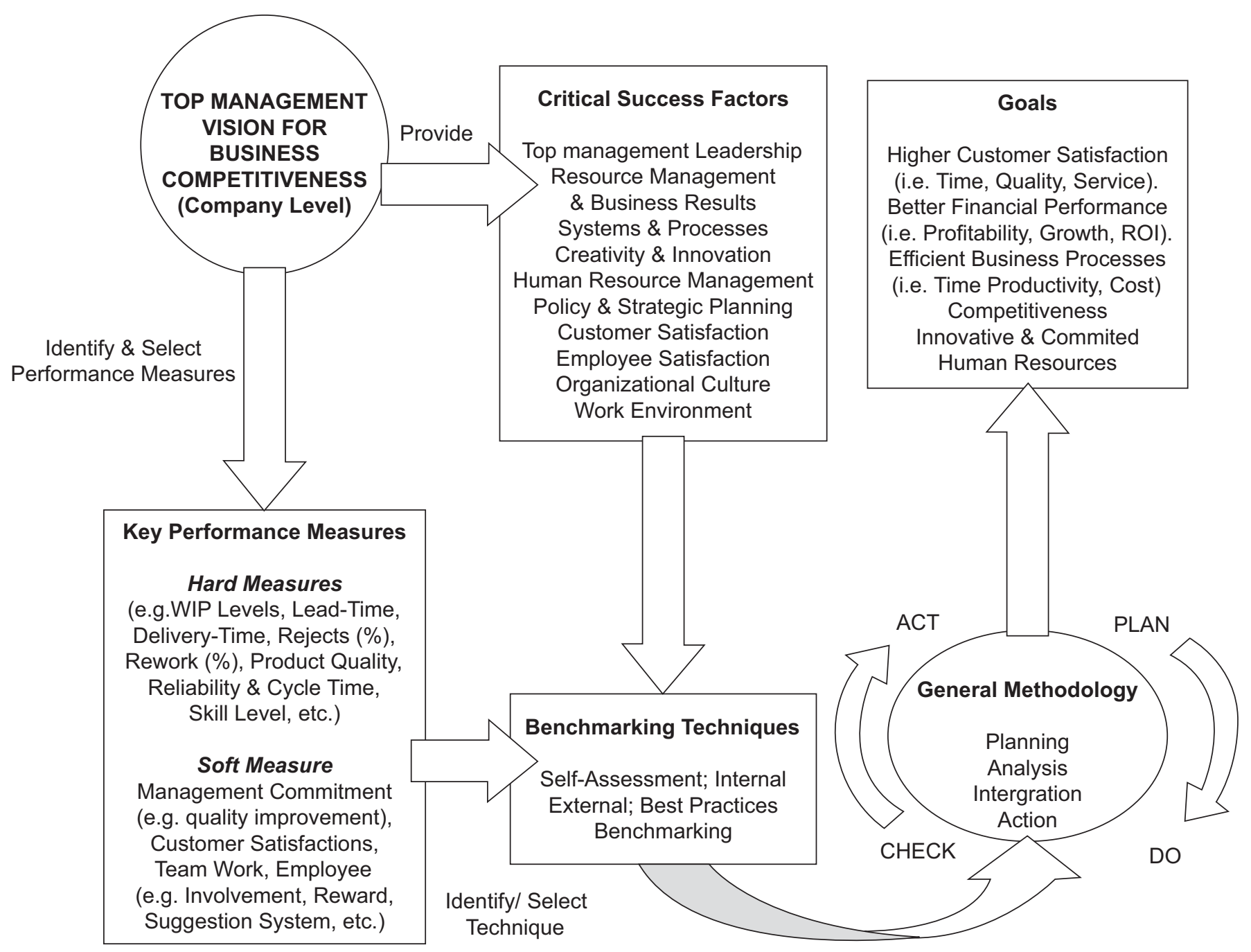

FIGURE 2. Proposed conceptual framework for benchmarking implementation in SMEs

structure, systems and procedures, culture and behaviour, human resources, market and customers), the two most important CSFs, which act as enablers and helps to drive the benchmarking implementation and adoption are management culture and behaviour (such as operations and behaviour of employees are largely influence by owners'/top management ethos and outlook, business result-oriented, etc.) and resource management (such as lack of financial, technical and human resources). Thus, it must be borne in mind that the various benchmarking techniques (such as selfassessment, internal, external and best practices) are to be implemented and adopted in stages, only when they are needed, and when the organization culture and behaviour is ready and not applied wholesale. In addition, gradual progress in benchmarking implementation will ensure success and ultimately result in adopting those initiatives, which are important for the SMEs continuous existence and survival in the market place.

Furthermore, benchmarking is one of the tools (and 'not' the only tool) found in quality improvement initiatives such as TQM. As such, prior to the benchmarking implementation and adoption, the SMEs should have implemented critical parts of the TQM programme such as top management leadership and organizational culture. This is important because these two enablers (i.e. CSFs) can help to provide an environment, which is conducive for benchmarking implementation and adoption.

Having identified the business process to be benchmarked and decide upon the benchmarking technique (for example, internal benchmarking), a sequence of activities will follow to ensure that it become the company's way of 'doing things'. The ultimate aim of 
benchmarking is to contribute towards continuous improvement in business processes. The general sequence of the improvement methodology is planning, analysis, integration and action. This cycle can be repeated until the key business process performance measures (i.e. soft and hard measures) and business goals (such as higher customer satisfaction, better financial performance, efficient business processes, competitiveness, etc.) are achieved. The same procedures also apply for the other benchmarking techniques. A diagram to show the mechanism for the overall concept of the framework is illustrated in Figure 2.

In summary, the concepts within the framework have been developed to be simple in nature and structure, not prescriptive, provide a systematic and 'work-book' approach, provide a general outline for benchmarking implementation on wholesale basis and encompass most of the pertinent issues with regards to benchmarking implementation. The framework does not suggest that all the concepts should be taken wholesale at-one-go, but rather one-at-a-time according to company needs and available resources. As already explained in previous section, due to their limited resources, SMEs actually need to begin the benchmarking and improvement initiatives in "tangible" measures (such as reject \%, rework \%, WIP levels, lead-time, etc.) rather than "intangible" measures, which are difficult to quantify in the form of numbers or percentages. This is important because positive results at the early stages of the benchmarking implementation would provide future motivation and thrust in benchmarking technique, which in turn, help to sustain the use of benchmarking practice in improving business and management processes, thus achieving business excellence and competitiveness.

\section{DISCUSSIONS ON THE VALIDATION OF A CONCEPTUAL FRAMEWORK FOR IMPLEMENTING BENCHMARKING IN SMES}

Having developed the proposed conceptual framework shown in Figure 2 for benchmarking implementation in SMEs, it was evaluated and validated in six case study companies. They were chosen as the case study companies based on their top management continuous effort and commitment towards achieving high quality, cost competitive and full on-time delivery of products to its customers (i.e. QCD). In this section, the authors shall discuss the general and specific comments, criticisms and suggestions made by case study companies' respondents concerning the framework's strengths and weaknesses. The authors shall begin the discussions, first by conducting a cross-case analysis across all the six case study companies, and then followed by each company's comments on the framework.

Referring to Table 3, all the six case study companies gave very positive comments on the proposed conceptual framework. They commented that it is feasible, easily understood and can be implemented with ease, a comprehensive approach and covers all the major aspects of the benchmarking implementation.It also provides a straightforward guide, which could simplify the benchmarking process even to someone who is new to the benchmarking concept. In short, the framework could be used as a base for conducting the benchmarking process even to beginners. Apart from that, most of them agreed the framework is a sensible approach towards conducting benchmarking initiatives in SMEs particularly that involves in the manufacturing sector.In addition, with some modifications in the key performance measures (i.e. hard and soft measures), the framework can be made applicable to other types of industries. Most of them highlighted that the top management's roles and responsibilities in the key areas of the framework should be in-place first before embarking on the actual benchmarking implementation effort in achieving the vision towards business competitiveness. For example, developing benchmarking strategies, policies, vision and mission for competitiveness should form an integral part of the business planning in an organisation.

They all agreed that top management must not only give their full commitment in providing sufficient resources but they must also be committed to implement the recommendations made by the benchmarking team. Meanwhile, five of the companies agreed that the framework's overall structure is sensible and suitable approach for SMEs to adopt while implementing benchmarking effort. In addition, four of them perceived the framework as practical, realistic and uncomplicated, which can easily be used in real working environment. Other positive comments raised by at least one of the case study company are the framework could 
give a clear and effective way of presenting the overall benchmarking concept; and it is a simple approach for incorporating benchmarking effort into a SME.

The case study companies also provide a few suggestions and constructive criticisms that could further enhance the framework's applicability and usability in SMEs. They are: (1) the vision and goal section should also include "competitiveness" advantages in the area of product quality, cost and delivery (i.e. QCD); (2) it is difficult to evaluate costs incurred against the improvement achieved especially the soft measures in benchmarking implementation; (3) a "target to be achieved" should also included in the general methodology section while conducting the review step because a "target" will drive the company to practice continuous improvement; (4) add continuous improvement and equipment utilisation in the key performance

TABLE 3. Comments and suggestions on the conceptual framework for benchmarking implementation

\section{Comments and Suggestions}

1. Its overall structure is a sensible and suitable approach for SMEs.

2. It is feasible, easily understood and can be implemented with ease.

3. It is a comprehensive approach and covers all the major aspects of the benchmarking implementation.

4. It provide a straight forward guide, which could simplify the process even to someone who is new to the benchmarking concept.

5. It gives a clear and effective way of presenting the general benchmarking concept.

6. It is a practical, realistic and uncomplicated framework, which can easily be used in real working environment.

7. It is a simple approach for incorporating benchmarking effort into a SME.

8. Vision and goal section should also include "competitiveness" advantages in the area of product quality, cost and delivery (i.e. QCD).

Framework

9. It is difficult to evaluate costs incurred against the improvement achieved especially the soft measures in benchmarking implementation.

10. A "target to be achieved" should also be included in the general methodology section while conducting the review step.

11. Add continuous improvement and equipment utilisation in the key performance measures section.

12. Human resource development and training should be focussed on educating the employees to improve positive work cultures practices.

$\begin{array}{llllll}1 & 2 & 3 & 4 & 5 & 6\end{array}$

$\begin{array}{lllll}2 & 2 & 2 & 2 & 2\end{array}$
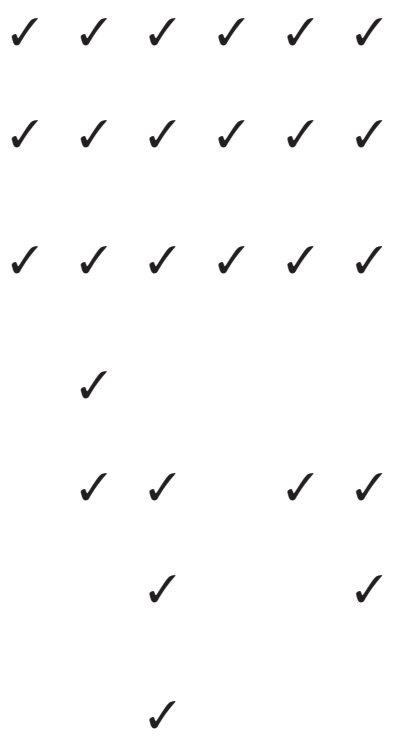

13. A dedicated coordinator is strongly required to ensure the benchmarking implementation program successfulness.

14. SMEs are always faced with resource constraints, therefore it should be taken into account during benchmarking effort. 
measures section because idle equipment and machineries did not produce any output. A high equipment utilisation indicates the company is maximising the usage of its available facilities, meanwhile, a low utilisation values indicates the machinery and equipment are under utilise; (5) human resource development and training should be focussed on educating the employees to improve their usage and practices of positive work cultures; (6) A dedicated coordinator is strongly required to ensure the benchmarking implementation program successfulness and (7) most SMEs are always constrained by limited availability of resources (i.e. financial, technical, human and time), therefore this aspect should be taken into account during benchmarking effort implementation. In addition, majority of case respondents agrees with the authors that the different types of benchmarking techniques and initiatives may be implemented according to the needs of the company and also depends on the resources availability and not applied wholesale.

\section{CONCLUSIONS}

This paper has shown how to develop a framework that could be use to help SMEs in implementing benchmarking efforts. It is therefore believed that this framework had provided an important contribution towards benchmarking implementation in SMEs because it had taken into account the characteristics and constraints of SMEs such as lack of resources, time and knowledge to use complicated frameworks to implement benchmarking. Many of the benchmarking frameworks found in the literature were the result of the work of benchmarking experts, working to the ideals of leaders of multinational organizations, which were designed and tested in large organizations and not SMEs. It has been shown that SMEs have different characteristics and thus face different problems compared to large organizations. For example, among the companies studied there was genuine frustration that they did not have the time and manpower dedicated to benchmarking effort and continuous improvement activities tended to be based on fire-fighting rather than with proper planning and prevention activities.

The findings from case study indicate that more SMEs need to be introduced to self-assessment, benchmarking and continuous improvement concepts. In order to be effective, these concepts must be brought to the SMEs because limited availability of money and people will often not allow SMEs to release their employees to attend outside courses. In the authors' opinion, this task of educating the SMEs should be carried out by organizations such as Small and Medium Development Corporation (SMIDEC), Standards Industrial Research Institute of Malaysia (SIRIM) and National Productivity Corporation (NPC).

With respect to the SMEs, the previous benchmarking implementation frameworks were not user "friendly" and consider as being daunting and not well suited to their needs. In other words, the SMEs need a framework, which leads them progressively and systematically down the benchmarking journey and continuous improvement process. To the SMEs, the framework must clearly identify and explain its requirement and then provide them the direction to follow. SMEs need a framework that enables them to proceed at their own speed and to educate them through the various stages of the benchmarking processes. SMEs are less likely to be familiar with the concepts of benchmarking and its associated benefits, thus needs to be led, therefore the benchmarking framework and the language used in the framework must be simple for them to understand.Therefore, it is important to design a framework that takes into account the working practices of the SMEs.

In addition, this framework has important strengths because it had been empirically validated in the SMEs environment. Even though the framework was developed specifically for the vendors in the automotive manufacturing sector, however, with some minor modifications in the key performance measures, it can be applied to all SMEs involved in the manufacturing industry. Furthermore, the framework is also believed to be useful to all companies because it was found that the process of achieving business competitiveness was focussed on the people who run the business processes with top management providing the CSFs and acts as the key driver. The case studies shows that the gradual implementation approach towards benchmarking adoption was practiced in all the SME companies.

In general, all businesses exist to provide product and services, which are required or needed by their customers. In the competitive market environment, particularly in the 
manufacturing industry, customers are more concern on these three factors, namely: product Quality, Costs and Delivery (QCD). These three factors are applicable and relevant in all manufacturing industries. Thus, it is believed the framework is generic because it provides a general approach towards benchmarking implementation and adoption. Lastly, the authors believed the conceptual framework presented would be able to assist many SMEs, which are still trying to be competitive through implementing

\section{REFERENCES}

Aalbregtse, R. J., Hejka, J. A. \& McNeley, P.K. 1991. Total Quality Management (TQM): How do you do it? Automation, August: 30-32.

Baumack, C. M. 1988. How to Organise and Operate Small Business, New Jersey: Prentice Hall, 8th Edition.

Carpinetti, L. C. R. \& De Melo, A. M. 2002. What to Benchmark? A Systematic Approach and Cases, Benchmarking: An International Journal, 9(3): 244-255.

Chee,L.P.1987.Industrial Development:An Introduction to the Malaysian Industrial Master Plan, Kuala Lumpur: Malaysia.

Dale, B. G. (ed.) 1994. Managing Quality, London: Prentice Hall.

Ghobadian, A.\& Gallear,D. 1997.TQM and Organization Size, International Journal of Operations \& Production Management, 17(2):121-163.

Ghobadian, A. \& Gallear, D. N. 1996. Total Quality Management in SMEs, Omega, International Journal Management Science, 24(1): 83-106.

Hashim, M.K.\&Wafa, S.A.2002.Small \& Medium Sized Enterprises in Malaysia - Development Issues, Kuala Lumpur: Prentice Hall.

Hornby, A. S. 1990. Oxford's Advanced Learner Dictionary of Current English, 4th Edition, Chief Editor: Cowie, A. P., Oxford University Press.

Huxtable, N. 1995. Small Business Total Quality, Chapman \& Hall, London.

Kraipornsak, P. 2002. The Plastic Industry of Thailand.

(http://www.econ.chula.ac.th/about/member/ paitoon_k/Thailand.pdf) 4th April 2002.

Medori,D.\&Steeple,D.2000."A Framework for Auditing and Enhancing Performance Measurement benchmarking, and also enrich the literature on benchmarking framework for SMEs.

\section{ACKNOWLEDGEMENTS}

The authors would like to thank the Ministry of Science Technology and Innovation (MOSTI) and Universiti Teknologi Malaysia for their support in providing the research grant for the project entitle "Development of an Integrated Quality Engineering Approach for Malaysian Automotive Industry" (IRPA 03-02-06-0060-EA254).

Systems, International Journal of Operations \& Production Management, 20(5):520-533.

Meredith, G. G. \& Grant, G. 1982. Small Business Management in Australia, London:McGraw-Hill, 2nd Edition.

Pickle, H. B. \& Abrahamson, R. L. 1990. Small Business Management, New York: John Wiley and Sons.

Popper, K. R. 1994, The Myth of the Framework: in Defence of Science and Rationality, London: Routledge.

Reed, F. M., Walsh, K. \& Grice, R. 2001. Supporting the Information Needs of Small Manufacturing Firms, 25th ISBA National Small Firms Policy and Research Conference, Competing Perspectives of Small Business and Entrepreneurship.

Salleh,M.\& Fichtner, G. 1991.Promotion of SMEs: Policy Environment and Institutional Framework, Kuala Lumpur: Government Printer.

Struebing, L. \& Klaus, L. A. 1997. Small Businesses Thinking Big, Quality Progress, February: 23-27.

Welsh, J. \& White, J. 1981. A Small Business is Not a Little Big Business, Havard Business Review, July - August : 18 - 32 .

Yusof, S. M. 2000. Development of a Framework for TQM Implementation in Small Business, Ph.D Thesis, Faculty of Engineering, University of Birmingham, U.K.

Yusof, S. M. \& Aspinwall, E. 2000a. A conceptual Framework for TQM Implementation for SMEs, The TQM Magazine, 12(1):31-36.

Yusof, S. M. \& Aspinwall E. 2000b. Total Quality Management Implementation Frameworks: Comparison and Review, Total Quality Management, 11(3): 281-294. 